\title{
Anti-angiogenic effects of differentiation-inducing factor-1 involving VEGFR-2 expression inhibition independent of the $\mathrm{Wnt} / \beta$-catenin signaling pathway
}

Tatsuya Yoshihara ${ }^{1,2}$, Fumi Takahashi-Yanaga ${ }^{1 *}$, Fumie Shiraishi', Sachio Morimoto', Yutaka Watanabe ${ }^{3}$, Masato Hirata ${ }^{4}$, Sumio Hoka ${ }^{2}$, Toshiyuki Sasaguri ${ }^{1}$

\begin{abstract}
Background: Differentiation-inducing factor-1 (DIF-1) is a putative morphogen that induces cell differentiation in Dictyostelium discoideum. DIF-1 inhibits proliferation of various mammalian tumor cells by suppressing the canonical Wnt/ $\beta$-catenin signaling pathway. To assess the potential of a novel cancer chemotherapy based on the pharmacological effect of DIF-1, we investigated whether DIF-1 exhibits anti-angiogenic effects in vitro and in vivo.

Results: DIF-1 not only inhibited the proliferation of human umbilical vein endothelial cells (HUVECS) by restricting cell cycle in the $G_{0} / G_{1}$ phase and degrading cyclin D1, but also inhibited the ability of HUVECs to form capillaries and migrate. Moreover, DIF-1 suppressed VEGF- and cancer cell-induced neovascularization in Matrigel plugs injected subcutaneously to murine flank. Subsequently, we attempted to identify the mechanism behind the antiangiogenic effects of DIF-1. We showed that DIF-1 strongly decreased vascular endothelial growth factor receptor-2 (VEGFR-2) expression in HUVECs by inhibiting the promoter activity of human VEGFR-2 gene, though it was not caused by inhibition of the Wnt/ $\beta$-catenin signaling pathway.

Conclusion: These results suggested that DIF-1 inhibits angiogenesis both in vitro and in vivo, and reduction of VEGFR-2 expression is involved in the mechanism. A novel anti-cancer drug that inhibits neovascularization and tumor growth may be developed by successful elucidation of the target molecules for DIF-1 in the future.
\end{abstract}

\section{Background}

Angiogenesis is a multi-step process essential for tumor growth and metastasis, which involves endothelial cell proliferation, migration and capillary formation [1-4]. Among many soluble and matrix-derived angiogenic growth factors and regulators of angiogenesis involved in neovascularization, vascular endothelial growth factor (VEGF) plays a crucial role in the proliferation, migration and survival of vascular endothelial cells [2,5-7].

The VEGF family consists of six members, VEGF-A, VEGF-B, VEGF-C, VEGF-D, VEGF-E and the placenta growth factor (PLGF) $[4,7,8]$. Among them, VEGF-A is known as the most important factor for many

\footnotetext{
* Correspondence: yanaga@clipharm.med.kyushu-u.ac.jp 'Department of Clinical Pharmacology, Faculty of Medical Sciences, Kyushu University, Fukuoka 812-8582, Japan

Full list of author information is available at the end of the article

angiogenic processes. VEGF-A binds to two tyrosine kinase receptors, VEGFR-1 (Flt-1) and VEGFR-2 (KDR/ Flk-1) [2,8-11]. Signaling through VEGFR-1 is related to embryonic angiogenesis and acts as a regulator of VEGFR-2 $[7,8,12,13]$. Although the affinity of VEGFR-2 for VEGF is lower than that of VEGFR-1, VEGFR-2 is more potent than VEGFR-1 in stimulating endothelial cell proliferation and migration [11,14]. VEGFR-2 expression is almost restricted to vascular endothelial cells and it has been reported that VEGFR-2 expression was markedly up-regulated during chronic inflammation, wound repair and tumor growth $[5,15,16]$.

Differentiation-inducing factors (DIFs) were identified in Dictyostelium discoideum as morphogens required for stalk cell differentiation [17]. In the DIF family, DIF-1 (1-(3, 5-dichloro-2, 6-dihydroxy-4-methoxyphenyl)-1hexanone) was the first to be identified. The actions of 
DIFs are not limited to Dictyostelium and they strongly inhibit the proliferation of human cells $[18,19]$. Previously, we reported that DIFs inhibited the Wnt/ $\beta$-catenin signaling pathway via glycogen synthase kinase- $3 \beta$ (GSK-3 $\beta$ ) activation, leading to cell cycle arrest at $G_{0} / G_{1}$ phase through suppression of cyclin D1 expression in various human tumor cells [20-23]. It is well known that the Wnt/ $\beta$-catenin signaling pathway plays a number of key roles in embryonic development and maintenance of homeostasis in matured tissues. And also, this signaling pathway has been reported to play important roles in the proliferation and migration of endothelial cells, resulting in the promotion of angiogenesis [24-28].

In this study, we investigated the effect of DIF-1 on angiogenesis in in vitro and in vivo systems. We revealed that DIF-1 decreased the expression of VEGFR2 in protein and mRNA levels via the suppression of the promoter activity by a Wnt/ $\beta$-catenin signaling pathway-independent mechanism. Our results suggest that the suppression of VEGFR-2 expression could be one mechanism of the inhibition of angiogenesis induced by DIF- 1 and that DIF- 1 suppressed not only the Wnt/ $\beta$ catenin signaling pathway but also neovascularization.

\section{Results}

\section{DIF-1 inhibited HUVEC proliferation}

DIF-1 exhibits powerful anti-proliferative effects in various mammalian cells [18-23] and we previously reported that DIF-3 induced cell cycle arrest by reducing cyclin D1 in HUVECs [20]. In this present study, we first examined whether DIF-1 also inhibited HUVEC proliferation. As shown in Figure 1A, DIF-1 strongly inhibited HUVEC proliferation in a dose-dependent manner. This anti-proliferative effect was unlikely to be caused by cytotoxicity, because the number of dead cells indicated by the trypan blue exclusion test was not increased by treatment with DIF-1 (data not shown). We next examined the effects of DIF-1 on cell cycle distribution using flow cytometry. As shown in Figure 1B, the cell population in the $G_{0} / G_{1}$ phase significantly increased and the population in $S$ and $G_{2} / M$ phases decreased, indicating that DIF- 1 induced $G_{0} / G_{1}$ arrest in HUVECs. These results were consistent with that published in our previous reports [19-21].

\section{DIF-1 induced proteolysis of cyclin D1 in HUVECs}

We previously reported that DIF-1 had strong effects on cyclin D1 protein level $[21,22]$. Therefore, we examined the effects of DIF-1 on cyclin D1 protein quantity using HUVECs. DIF-1 rapidly reduced the protein level of cyclin D1 in time- and dose-dependent manners (Figure 2A and $2 \mathrm{~B}$, respectively). Next, we examined the effects of proteasome inhibitor MG132, since cyclin D1 has been reported to be degraded by ubiquitin-dependent proteolysis.
MG132 significantly attenuated the effects of DIF-1, indicating that DIF-1 induced proteolysis of cyclin D1 in HUVECs (Figure 2C).

\section{DIF-1 inhibited angiogenesis in vitro}

To evaluate the effects of DIF-1 on angiogenesis in vitro, we performed tube formation assay. HUVECs formed blood vessel-like structure (tubes) on Matrigel-coated wells following incubation for $8 \mathrm{~h}$. However, DIF-1-treated HUVECs almost failed to form vessel-like structures and the number of areas surrounded by tubes was significantly smaller than that in control cells (Figure 3A). Subsequently, the effects of DIF-1 on HUVECs migration were evaluated using a Boyden Chamber. Although the cells migrated into the lower chamber even in the absence of VEGF, the number of migrating cells increased by about $30 \%$ when VEGF was added to the lower chamber. Therefore, VEGF was added to the lower chamber when the effect of DIF-1 was investigated. Although VEGF in the lower chamber induced cell migration after incubation for $10 \mathrm{~h}$, DIF-1 significantly reduced the number of migrated cells (Figure 3B). These results clearly indicated that DIF-1 inhibited angiogenesis in vitro.

\section{DIF-1 inhibited angiogenesis in vivo}

We examined the effects of DIF-1 on angiogenesis in vivo by Matrigel plug assay. VEGF containing-Matrigel was prepared with or without DIF-1 $(30 \mu \mathrm{M})$ and injected into the flanks of mice. As shown in Figure 4, blood vessels indicated by the expression of PECAM-1/ CD31, an endothelial cell-specific antigen, were strongly induced into the injected Matrigel plugs. On the other hand, the level of PECAM-1/CD31 expression was significantly lower in DIF-1-containing Matrigel plugs than in the control plugs, indicating the presence of fewer blood vessels.

Subsequently, we examined the effects of DIF-1 on tumor-induced angiogenesis using HeLa cells. Two weeks after injection, Matirgel/HeLa cell mixture formed tumor mass and blood vessels were grown into the mass. Immunohistochemical analysis of PECAM-1/ CD31 in tumor masses clearly showed that the content of blood vessels was much less in DIF-1-containing masses (Figure 5A-I). This finding was also confirmed by Western blot analysis. As shown in Figure 5J, the level of PECAM-1/CD31 expression was significantly lower in DIF-1-containing masses than in the control masses. These results indicated that DIF-1 inhibited blood vessel growth induced by VEGF and tumor cells.

DIF-1 decreased VEGFR-1 and VEGFR-2 protein expression It is well known that VEGF-A, a major regulator for angiogenesis, binds to VEGFR-1 (Flt-1) and VEGFR-2 


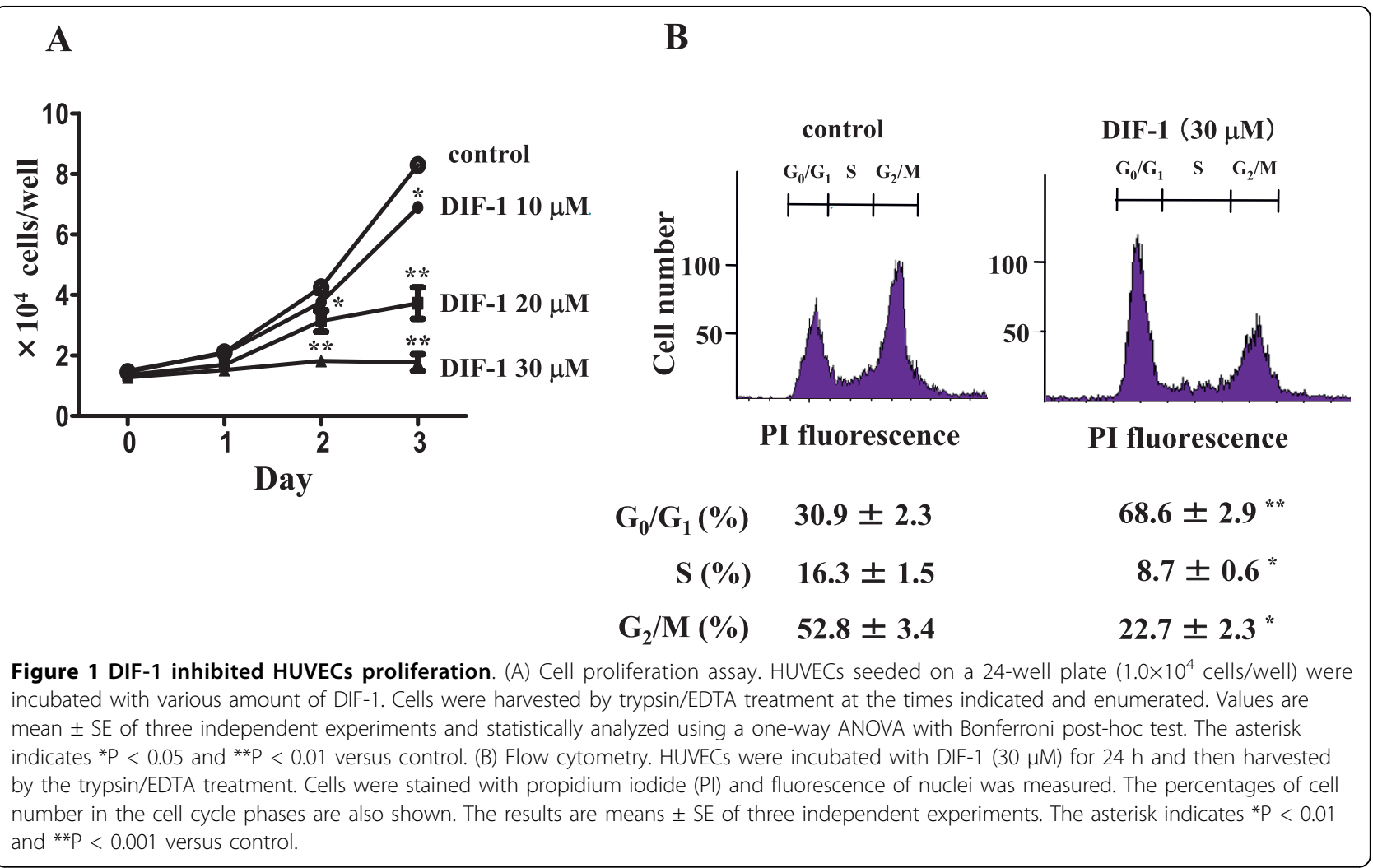

(KDR/Flk-1) to transduce its signal. To clarify the mechanism by which DIF-1 suppresses angiogenesis, first we examined the effects of DIF-1 on VEGFR-1 and VEGFR-2 expression in HUVECs by Western blot analysis. As shown in Figure 6A, although DIF-1 significantly reduced the expression of both receptors in HUVECs, the effect was much stronger in VEGFR-2 than VEGFR-1.

VEGF increases VEGFR-2 phosphorylation on $\mathrm{Tyr}^{1175}$ for activation [29-31]. Although DIF-1 decreased the phosphorylation level of $\mathrm{Tyr}^{1175}$ on VEGFR-2 in a timedependent manner, it was parallel with the time course of the VEGFR-2 protein amount, indicating that DIF-1 had no significant effects on the level of VEGFR-2 phosphorylation (Figure 6B).

\section{DIF-1 reduced VEGFR-2 protein synthesis}

To clarify the mechanism of DIF-1-induced VEGFR-2 protein suppression, we first examined the effects of DIF-1 on VEGFR-2 degradation using protein synthesis inhibitor cycloheximide. As shown in Figure 7A, DIF-1 did not accelerate reduction in VEGFR-2 protein quantity, indicating that DIF-1 had no significant effects on VEGFR-2 proteolysis.

Next, we investigated VEGFR-2 protein synthesis. HUVECs were pretreated with cycloheximide for $3 \mathrm{~h}$ and then the medium was changed to fresh growth medium to wash out cycloheximide. As shown in Figure 7B, after VEGFR-2 protein disappeared following cycloheximide treatment, it was rapidly restored and reached a plateau after $1 \mathrm{~h}$ incubation. However, restoration of VEGFR-2 protein was significantly delayed by DIF-1 treatment.

\section{DIF-1 suppressed VEGFR-2 mRNA level and VEGFR-2 promoter activity}

Subsequently, we examined the effect of DIF-1 on the mRNA expression of VEGFR-2 in HUVECs by real-time PCR analysis and found that DIF-1 significantly suppressed VEGFR-2 mRNA level (Figure 8A). We further examined the effects of DIF-1 on human VEGFR-2 gene promoter activity using a luciferase reporter plasmid. Since the efficiency of DNA transfection in HUVECs was low (10\% to $20 \%$ ), we also employed BAECs in which transfection efficiency was much higher $(60 \%$ to $70 \%$ ) [32]. As shown in Figure $8 \mathrm{~B}$ and $8 \mathrm{C}$, luciferase reporter activity driven by the 5 '-flanking region of human VEGFR-2 gene in HUVECs (B) or BAECs (C) was increased as incubation proceeded. However, the promoter activity was not significantly increased in DIF1-treated HUVECs and BAECs. Therefore DIF-1 appeared to suppress VEGFR-2 protein and mRNA expressions by inhibiting the promoter activity in HUVECs. 


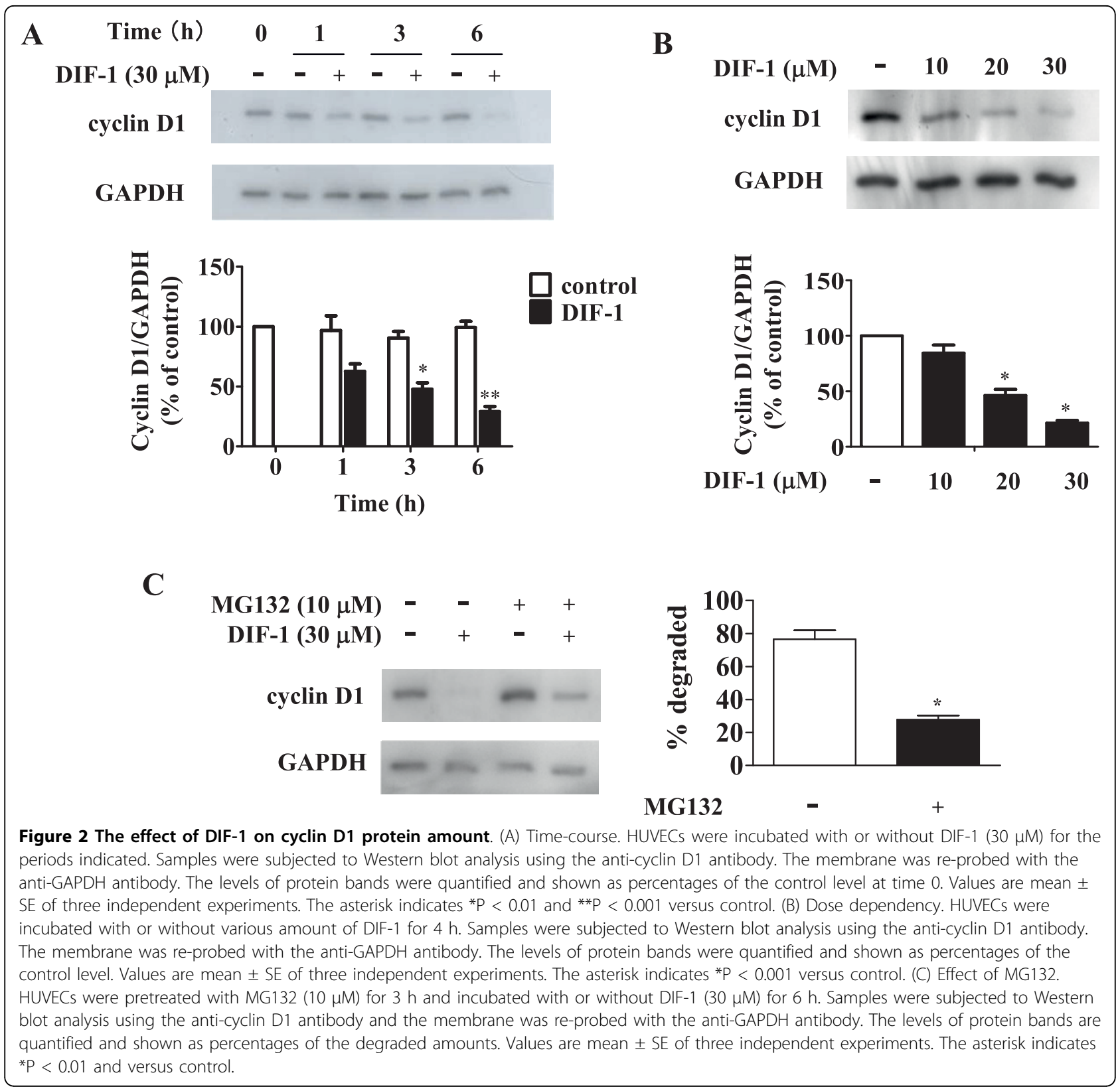

\section{Wnt-3a suppressed VEGFR-2 promoter activity}

As previously reported, DIF-1 suppressed the Wnt/ $\beta$ catenin signaling pathway by activating GSK-3 $\beta$ in tumor cells. Moreover, the Wnt/ $\beta$-catenin signaling pathway has been shown to play an important role in promoting angiogenesis. Therefore, we examined the involvement of the Wnt/ $\beta$-catenin signaling pathway in DIF-1-induced VEGFR-2 suppression. As shown in Figure 9A, DIF-1 significantly inhibited TOPflash (TCF reporter plasmid) activity, whereas it did not affect FOPflash (negative control) activity. Furthermore, as shown in Figure 9B, DIF-1 reduced the phosphorylation level of Ser $^{9}$ on GSK-3 $\beta$, indicating that DIF-1 certainly inhibited the Wnt/ $\beta$-catenin signaling pathway by activating GSK-3 $\beta$ in HUVECs.

Although VEGF is one of the target genes of the Wnt/ $\beta$-catenin signaling pathway $[33,34]$, it has not been elucidated whether VEGFR-2 gene also belongs to the target genes of this signaling pathway. Therefore, the effects of Wnt3a as an activator of the Wnt/ $\beta$-catenin signaling pathway on VEGFR-2 protein expression were examined. Although the amount of VEGFR-2 protein was increased after a $24 \mathrm{~h}$-incubation period, treatment with Wnt3a suppressed VEGFR-2 protein increase (Figure 10A). This observation was confirmed by the luciferase reporter assay using the 5'-flanking region of 


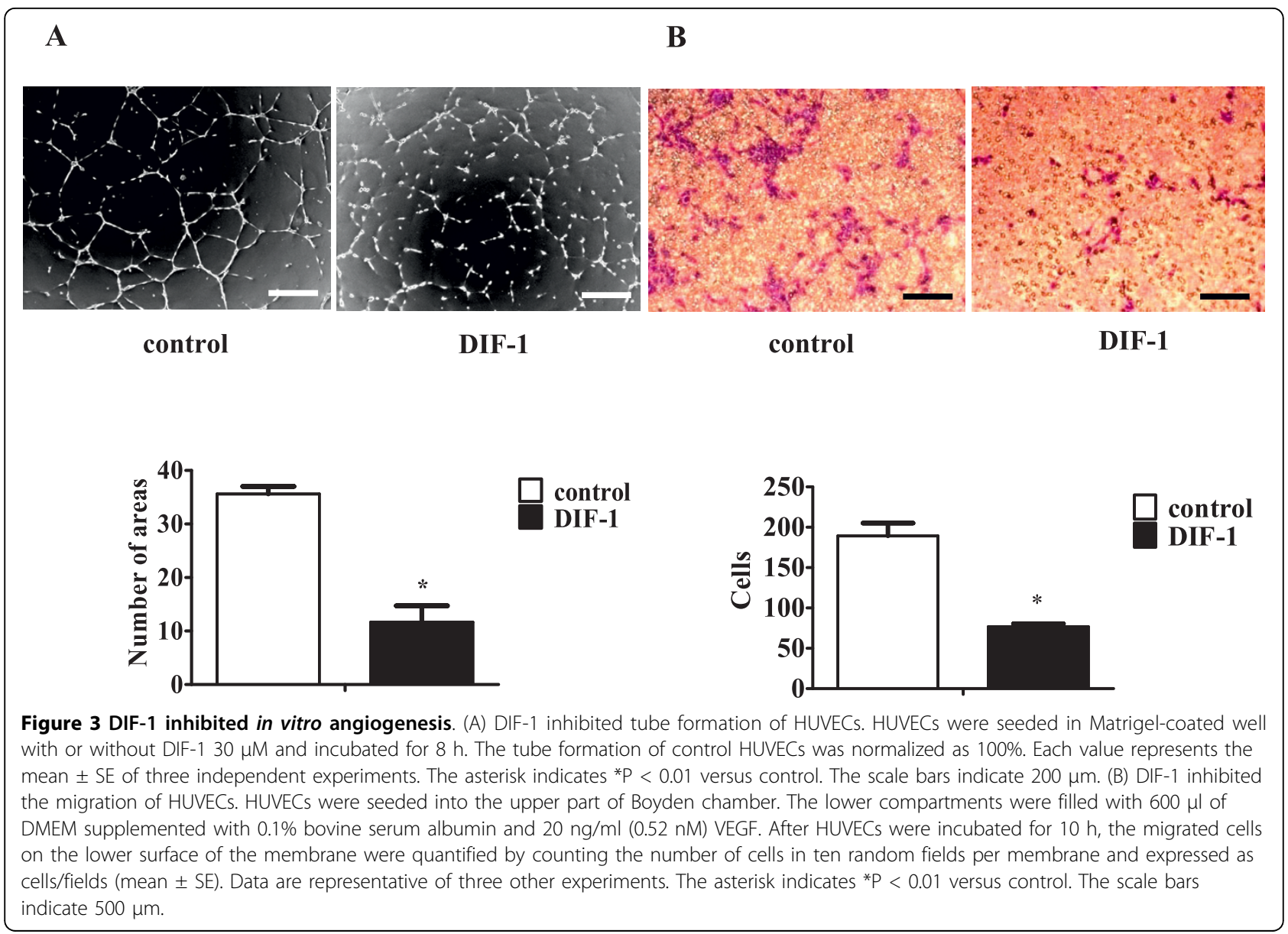

the human VEGFR-2 gene. As shown in Figure 10B, Wnt3a suppressed VEGFR-2 promoter activity slightly but significantly in HUVECs, whereas it clearly increased TOPflash activity. These results indicated that Wnt3a suppressed VEGFR-2 expression via inhibition of promoter activity, suggesting that VEGFR-2 gene expression was suppressed by activating the Wnt/ $\beta$-catenin signaling pathway.

Taken together, although DIF-1 suppressed the Wnt/ $\beta$-catenin signaling pathway in HUVECs as well as tumor cells, inhibition of VEGFR-2 promoter activity induced by DIF-1 was not due to suppression of this signaling pathway.

\section{Discussion}

In this study, we demonstrated that DIF-1 strongly inhibited angiogenesis in vitro and in vivo. As it is known that VEGF-A signal plays a prominent role in angiogenesis, we paid special attention to two types of VEGF receptors, VEGFR-1 and VEGFR-2. Although DIF-1 decreased the levels of protein expression of both receptors on HUVECs, the effects were faster and stronger in VEGFR-2 than VEGFR-1. Activation of VEGFR-2 by VEGF-A depends on the phosphorylation status of several tyrosine residues (such as 951, 1059, 1175, and 1214) in VEGFR-2. Among these tyrosine residues, $\mathrm{Tyr}^{1175}$ is the binding site of phospholipase-C $\gamma$, a main signal transducer of VEGFR-2 [32-34]. However, as shown in Figure 6B, DIF-1 did not have significant effects on the Tyr ${ }^{1175}$ phosphorylation status, suggesting that DIF-1 did not affect VEGFR-2 activation. Since VEGFR-2 is a direct signal transducer for pathological angiogenesis as observed in cancers, the powerful reduction of VEGFR-2 protein levels may be involved in DIF1 induced anti-angiogenic effects.

We also attempted to clarify the mechanism by which DIF-1 reduced the amount of VEGFR-2 protein. DIF-1 affected the synthesis rather than proteolysis of VEGFR2 . This was consistent with the result that DIF-1 inhibited the mRNA expression and promoter activity of VEGFR-2. However, degrees of suppression of the mRNA expression (29\%) and promoter activity (24\%) were relatively small compared to VEGFR-2 protein quantity suppression (93\%) after 24 h-treatment with DIF-1. The same sort of phenomenon was also observed by Wnt3a (16\% promoter activity suppression vs. $34 \%$ 


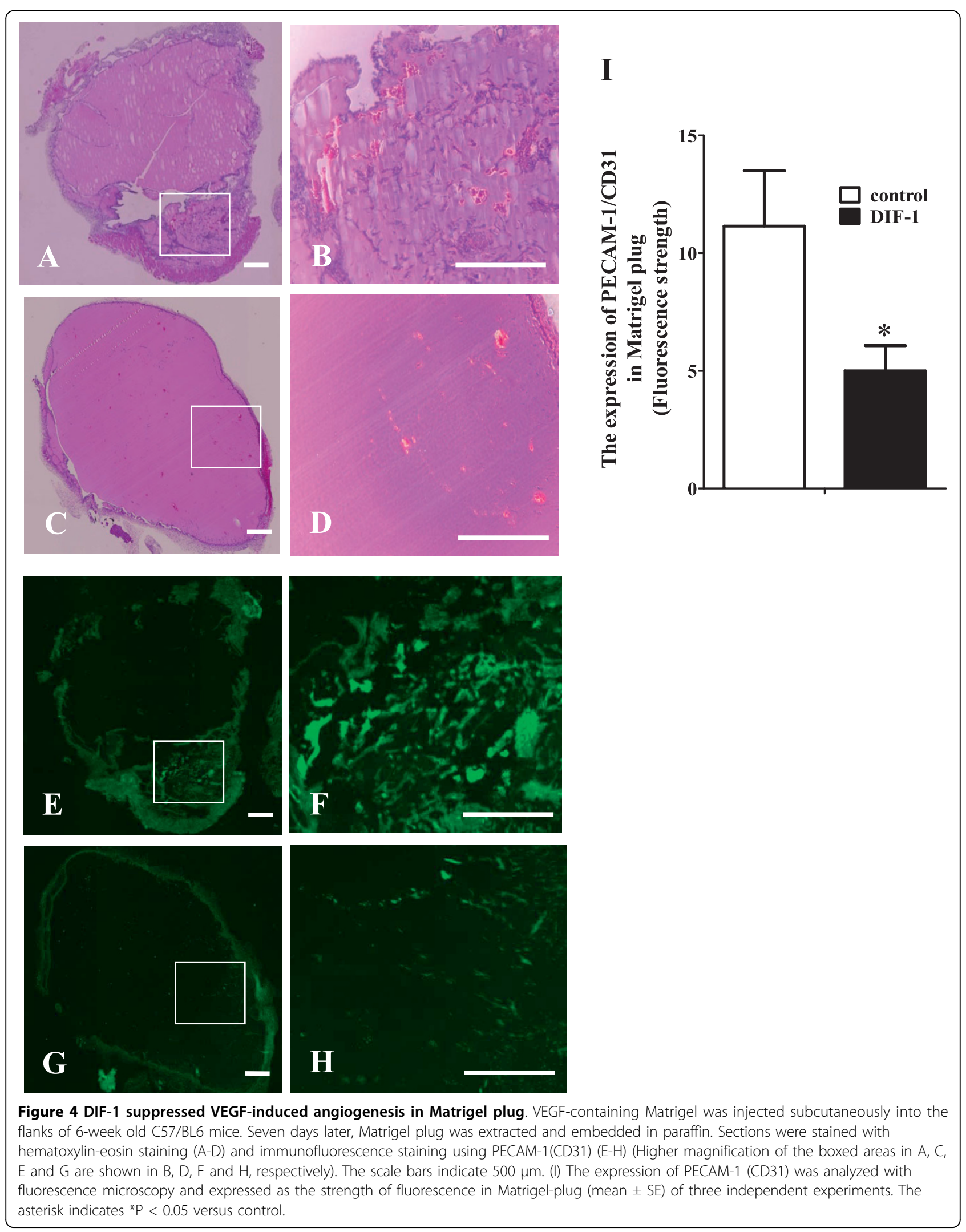




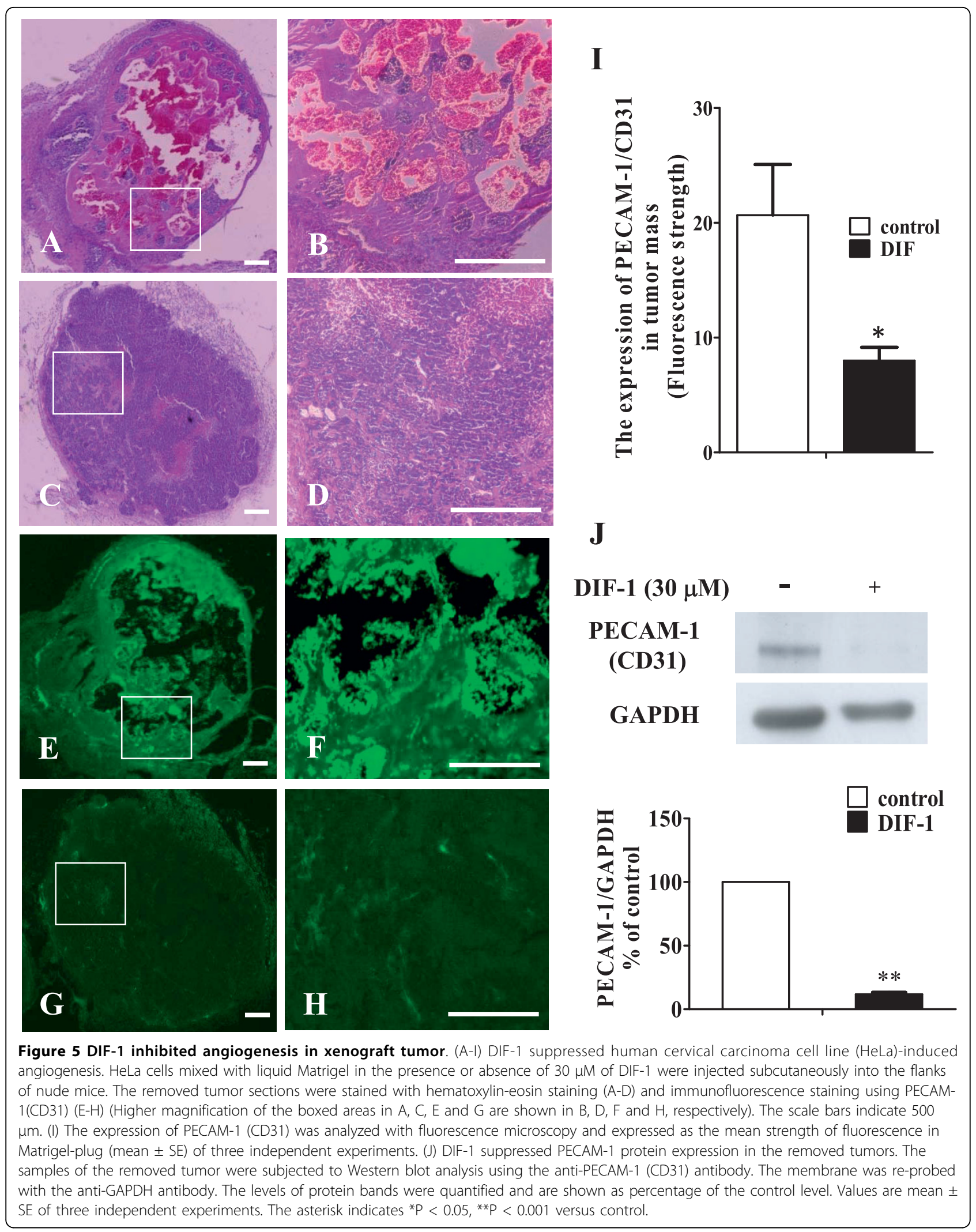




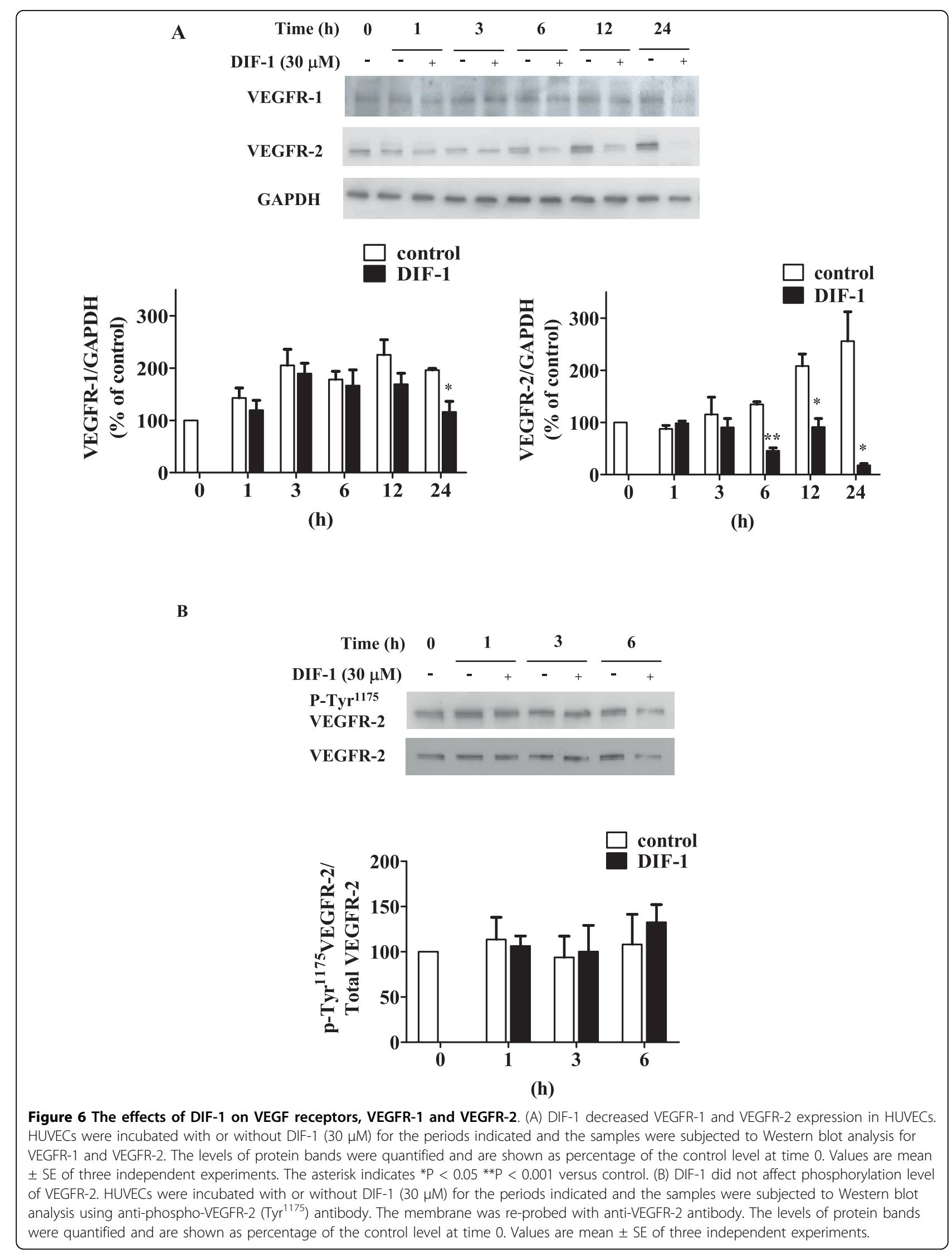




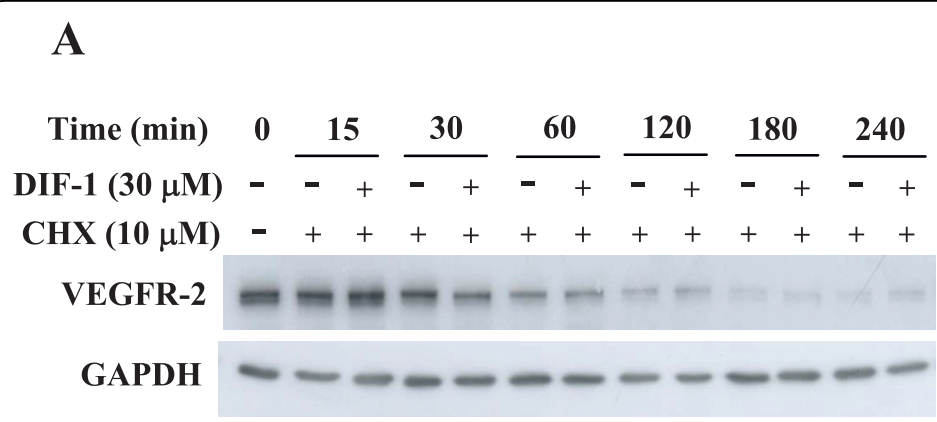

B

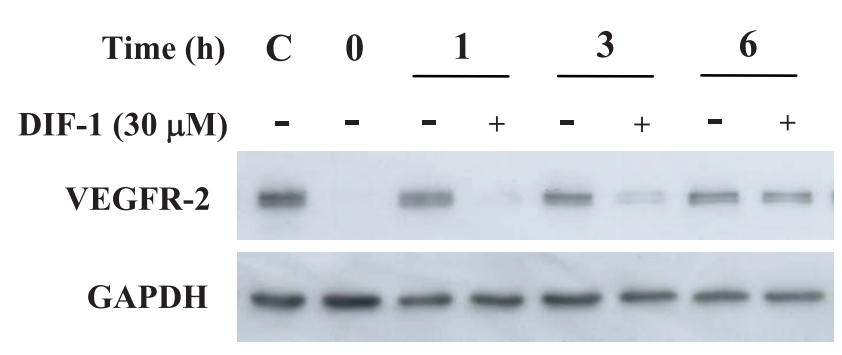

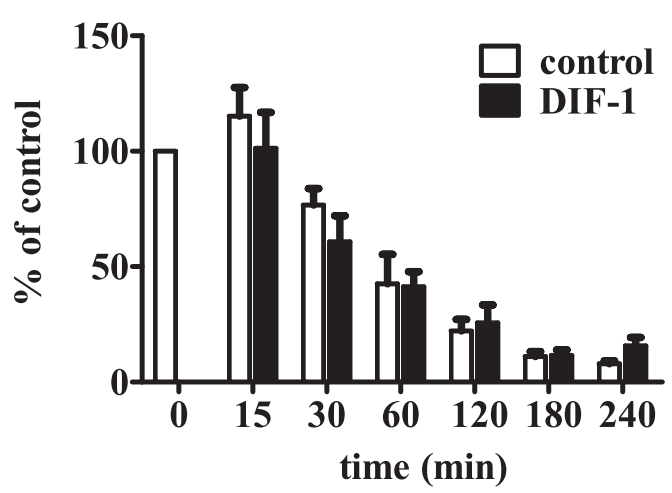

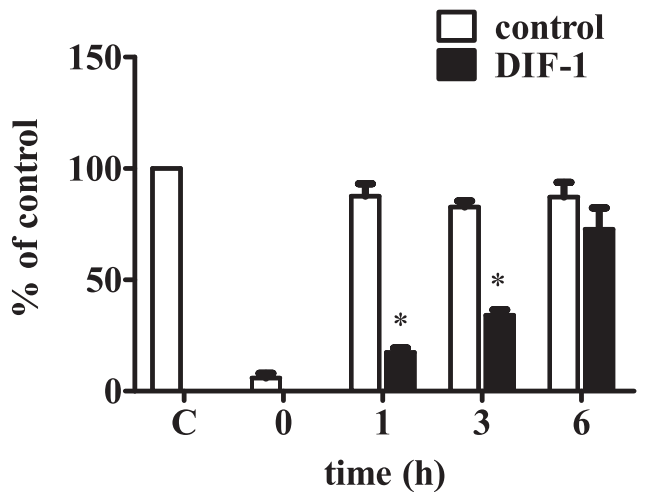

Figure 7 The effects of DIF-1 on the proteolysis and the proteosynthesis of VEGFR-2. (A) DIF-1 did not affect the degradation speed of VEGFR-2. HUVECs were incubated with or without DIF-1 $(30 \mu \mathrm{M})$ for the given periods in the presence of cycloheximide $(10 \mu \mathrm{M})$. Protein samples were subjected to Western blot analysis for VEGFR-2. The membrane was re-probed with anti-GAPDH antibody. The levels of protein bands were quantified and are shown as percentage of the control level at time 0 . Values are mean \pm SE of three independent experiments. (B) DIF-1 attenuated the protein synthesis of VEGFR-2. After HUVECs were pretreated with cycloheximide $(10 \mu \mathrm{M})$ for $3 \mathrm{~h}$, the medium was changed to fresh medium and cells were incubated with or without DIF-1 $(30 \mu \mathrm{M})$ for the given periods. Protein samples were subjected to Western blot analysis for VEGFR-2. The membrane was re-probed with anti-GAPDH antibody. The levels of protein bands were quantified and are shown as percentage of the control cells which were not treated with cycloheximide (lane 1). Values are mean \pm SE of three independent experiments. The asterisk indicates $* P<0.001$ versus control.

protein quantity suppression). Although we could not explain this difference at present, the short half-life of VEGFR-2 protein of about $1 \mathrm{~h}$ [35] could be associated with this phenomenon. In other words, as the proteolysis of VEGFR-2 is quick and rapid synthesis is required to restore VEGFR-2, even weak inhibition of promoter activity may significantly affect the quantity of VEGFR-2 protein.

Since we have shown that DIF-1 inhibits the Wnt/ $\beta$ catenin signaling pathway in various cells, the effects of DIF-1 on the Wnt/ $\beta$-catenin signaling pathway in HUVECs were examined. We found that DIF-1 also inhibited this signaling pathway via GSK-3 $\beta$ activation in HUVECs. Although the Wnt/ $\beta$-catenin signaling pathway has been reported to be important to promote angiogenesis in vitro [24-28], the role of $\mathrm{Wnt} / \beta$-catenin signaling pathway in endothelial cells and angiogenesis is controversial. Cheng et al. reported that Wnt1 signaling inhibits HUVEC proliferation [36]. On the other hand, it has been reported that Wnt1 and 3a mediated induction of VEGFR-2 (Quek-1) expression during avian somite development [37]. In this study, we showed that Wnt3a slightly but significantly reduced promoter activity and VEGFR-2 protein expression. Therefore, suppression of VEGFR-2 expression induced by DIF- 1 may not be due to suppression of the Wnt $/ \beta$ catenin signaling pathway. Our results might suggest that activation of the $\mathrm{Wnt} / \beta$-catenin signaling pathway suppressed the promotion of angiogenesis. However, Samarzija et al. showed that although Wnt3a stimulated HUVEC proliferation and migration independent of VEGFR signaling [38]. Therefore, further studies are needed to elucidate the relationship between the Wnt/ $\beta$-catenin signaling pathway and angiogenesis.

Cyclin D1 plays a key role in the initiation and progression of the $G_{1}$ phase [39]. We previously showed 


\section{A}
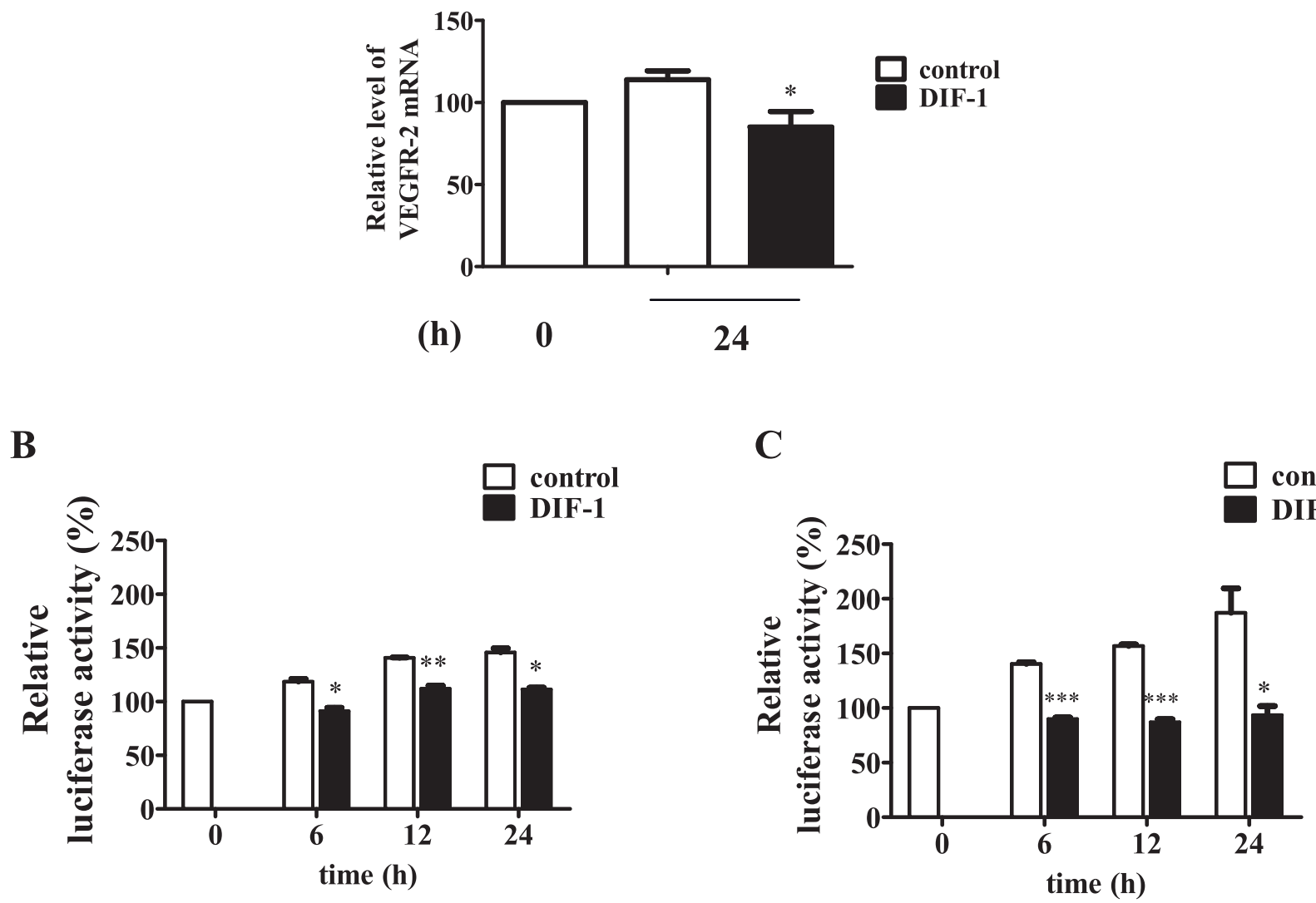

Figure 8 DIF-1 reduced VEGFR-2 mRNA level and promoter activity. (A) The effects of DIF-1 on the VEGFR-2 mRNA levels. Total RNAs were extracted from HUVECs treated with or without DIF-1 $(30 \mu \mathrm{M})$ for $24 \mathrm{~h}$. The VEGFR-2 mRNA levels were determined by TaqMan quantitative realtime RT-PCR. Values are mean \pm SE of four independent experiments. The asterisk indicates $* P<0.05$ versus control. (B and C) The effects of DIF1 on the human VEGFR-2 gene promoter activity on HUVECs (B) or BAECs (C). HUVECs or BAECs were co-transfected with VEGFR-2 pGL-3 and pRL-SV40. After $24 \mathrm{~h}$ incubation, HUVECs and BAECs were stimulated with or without DIF-1 (30 $\mu \mathrm{M})$ for the given periods. Luciferase activity is shown as percentages of the control level at time 0 . Values are mean \pm SE of three independent experiments. The asterisk indicates ${ }^{*} P<0.01$ ${ }^{*} \mathrm{P}<0.001{ }^{* * *} \mathrm{P}<0.0001$ versus control.

that DIF-1 and DIF-3 reduced cyclin D1 quantity and induced cell cycle arrest in $G_{0} / G_{1}$ phase using various mammalian cells $[19,21,22]$. In this study, we also demonstrated that DIF-1 inhibited HUVECs proliferation and induced restriction of cell cycle in the $G_{0} / G_{1}$ phase by degrading cyclin D1. This result is consistent with that published in our previous reports, and indicates that cyclin D1 also plays an important role in HUVEC proliferation. Furthermore, it has been reported that antisense to cyclin D1 inhibited tumor-associated neovascularization [40]. As such, suppression of cyclin D1 expression may be one of the anti-angiogenesis mechanisms induced by DIF-1.

\section{Conclusions}

In summary, we found that DIF-1 reduced the expression of cyclin D1 and VEGFR-2 in HUVECs. The reduction of cyclin D1 and VEGFR-2 expression may inhibit proliferation, and reduction of VEGFR-2 may cause inhibition of migration and tube formation. These effects may explain the powerful anti-angiogenic properties of DIF-1.

We previously reported that DIF-1 showed anti-tumor activity by inhibiting cyclin D1 expression and the Wnt/ $\beta$-catenin signaling pathway. In addition to these effects, this study demonstrated that DIF- 1 also exhibited antiangiogenic effects independent of the $\mathrm{Wnt} / \beta$-catenin signaling pathway. Elucidation of the target molecule of DIF-1 will facilitate the development of potent novel anti-tumor agents which suppresses not only the Wnt/ $\beta$-catenin signaling pathway but also angiogenesis.

\section{Methods}

\section{Cell Culture}

Human umbilical vein endothelial cells (HUVECs) were purchased from DS Pharma Biomedical (Osaka, Japan). 
A

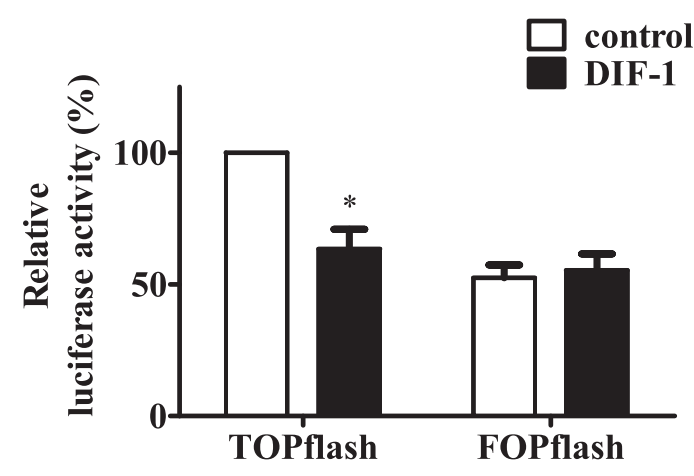

B

p-Ser' GSK-3 $\beta$

GSK-3 $\beta$
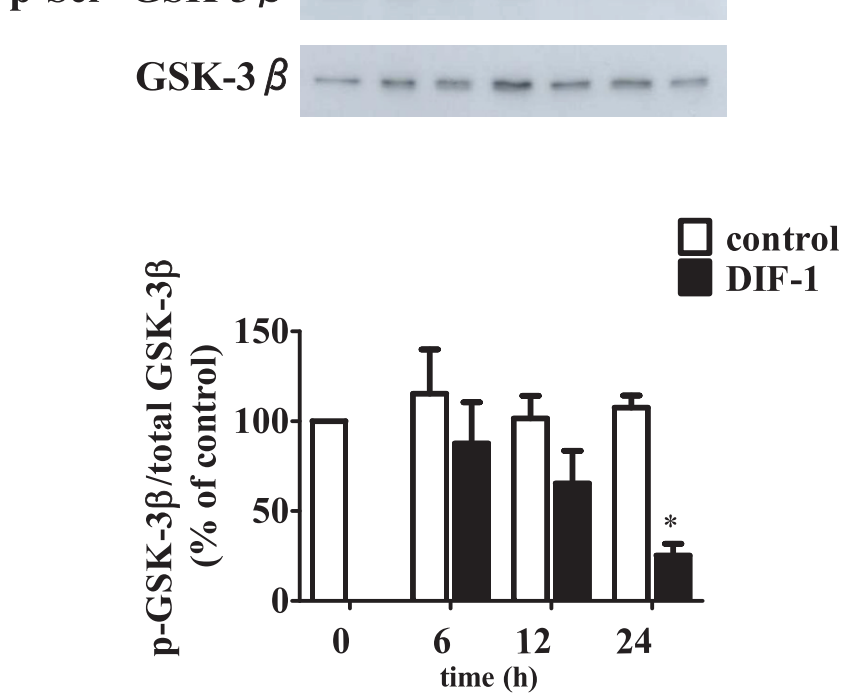

Figure 9 DIF-1 suppressed Wnt/ $\beta$-catenin signaling pathway in HUVECs. (A) Effect of DIF-1 on TCF transcriptional activity. TOPflash or FOPflash was co-transfected with pRL-SV40 into HUVECs. After $24 \mathrm{~h}$ incubation, HUVECs were stimulated with or without DIF-1 (30 $\mu \mathrm{M})$ for $24 \mathrm{~h}$. Luciferase activity is shown as percentages of the control level. Values are mean \pm SE of three independent experiments. The asterisk indicates ${ }^{*} \mathrm{P}<0.01$ versus control. (B) DIF-1 activated GSK-3 $\beta$. HUVECs were incubated with or without DIF-1 $(30 \mu \mathrm{M})$ for given periods. Protein samples

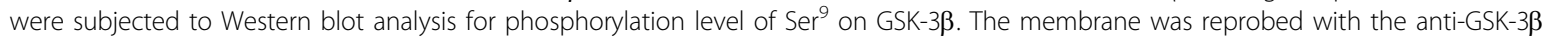
antibody. The levels of protein bands were quantified and are shown as percentage of the control level at time 0 . Values are mean \pm SE of three independent experiments. The asterisk indicates ${ }^{*} \mathrm{P}<0.0001$ versus control.

The cells were grown in Dulbecco's modified Eagle's medium (Sigma-Aldrich, St Louis, Mo, USA) supplemented with $20 \%$ fetal bovine serum, $5 \mathrm{ng} / \mathrm{ml}(0.29 \mathrm{nM})$ recombinant human basic fibroblast growth factor (PeproTech, Rocky Hill, NJ, USA), 100 units/ml penicillin G, and $100 \mu \mathrm{g} / \mathrm{ml}$ streptomycin using $0.1 \%$ gelatin coated dishes. HeLa cells (human cervical carcinoma cell line) and bovine aortic endothelial cells (BAECs) were grown in Dulbecco's modified Eagle's medium (DMEM) (SigmaAldrich) supplemented with $10 \%$ fetal bovine serum, 100 units/ml penicillin $\mathrm{G}$ and $100 \mu \mathrm{g} / \mathrm{ml}$ streptomycin.

\section{Reagents and antibodies}

DIF-1 (1-(3,5-dichloro-2, 6-dihydroxy-4-methoxyphenyl)1-hexanone) was synthesized as described previously [41]. MG132 was obtained from the Peptide Institute (Osaka, Japan). Cycloheximide was obtained from SigmaAldrich. Polyclonal anti-cyclin D1 antibody, polyclonal anti-PECAM-1 (CD31) antibody and the polyclonal antiVEGFR-1/Flt-1 antibody were purchased from Santa Cruz Biotechnology (CA, USA). Monoclonal antiVEGFR-2 antibody and the monoclonal anti-phospho-
VEGFR-2 (Tyr $\left.{ }^{1175}\right)$ antibody were from Cell Signaling Technology (Danvers, MA, USA). The monoclonal GAPDH antibody was obtained from Abcam (Cambridge, MA, USA). Growth factor reduced Matrigel was obtained from BD Biosciences (San Jose, CA, USA). TOPflash (TCF reporter plasmid) and FOPflash (negative control of TOPflash) were purchased from Upstate Biotechnology (Lake Placid, NY, USA). Human Wnt3a was from R\&D Systems (Minneapolis, MN, USA).

\section{Cell proliferation assay}

The cells were plated on 24 -well plates $\left(1.0 \times 10^{4}\right.$ cells/ well) and treated with or without various amounts of DIF-1 for defined periods. Cells were harvested by trypsin/EDTA treatment and enumerated using Coulter Counter (Beckman Coulter, Brea, CA, USA).

\section{Flow Cytometry}

Cells harvested by trypsin/EDTA treatment were suspended in hypotonic fluorochrome solution containing $50 \mu \mathrm{g} / \mathrm{ml}$ of propidium iodide, $0.1 \%$ sodium citrate, and $0.1 \%$ Triton $\mathrm{X}-100$. Cells $\left(5 \times 10^{3}\right)$ for each sample were 
$\mathbf{A}$
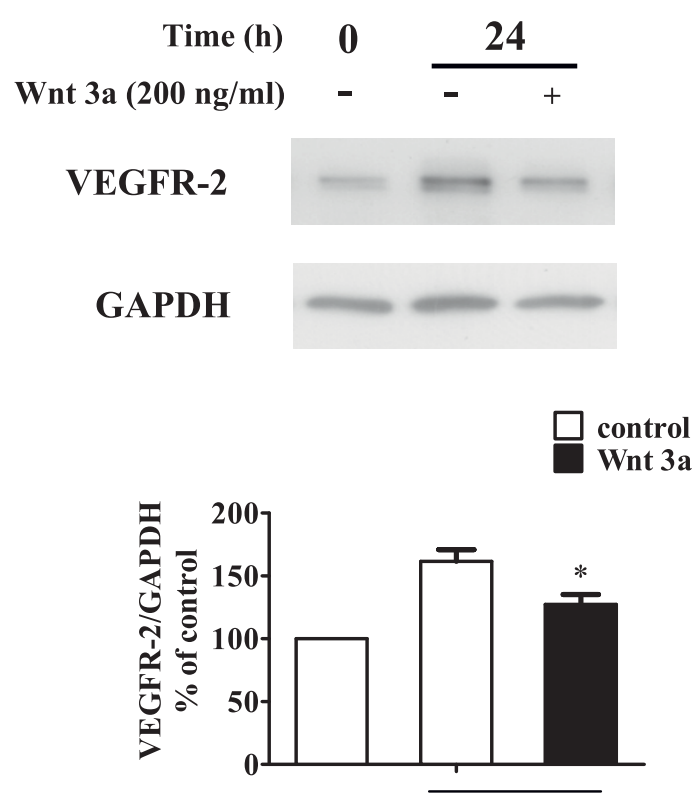

(h)
B
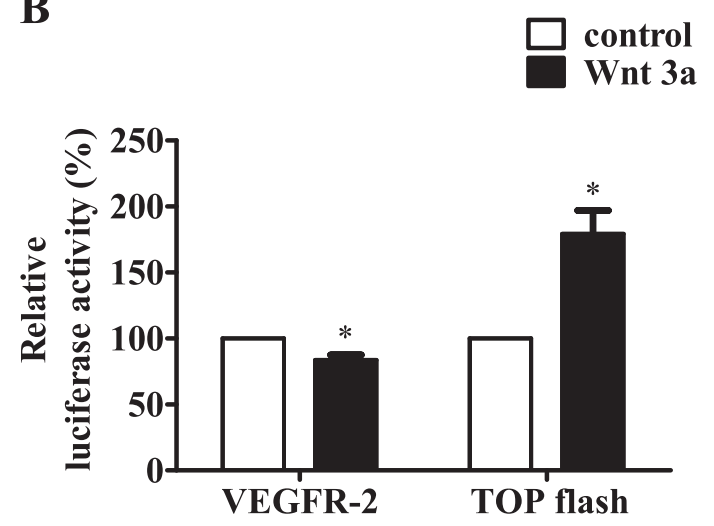

Figure 10 Effects of Wnt3a on VEGFR-2. (A) Wnt3a suppressed VEGFR-2 expression. HUVECs were incubated with or without Wnt3a (200 ng/ $\mathrm{ml}=5.35 \mathrm{nM}$ ) for $24 \mathrm{~h}$ and the samples were subjected to Western blot analysis for VEGFR-2. The levels of protein bands were quantified and are shown as percentage of the control level at time 0 . Values are mean \pm SE of three independent experiments. The asterisk indicates ${ }^{*} P<0.05$ versus control. (B) Wnt3a suppressed the VEGFR-2 promoter activity. HUVECs were co-transfected with VEGFR-2 pGL-3 or TOPflash and pRL-SV40. After $24 \mathrm{~h}$ incubation, cells were stimulated with or without Wnt3a (200 ng/ml) for $12 \mathrm{~h}$. Luciferase activity is shown as percentages of the control. Values are mean \pm SE of three independent experiments. The asterisk indicates ${ }^{*} \mathrm{P}<0.05$ versus control.

analyzed for fluorescence by a Becton-Dickinson FACScalibur (Franklin Lakes, NJ, USA).

\section{Western blotting}

Samples were separated by 10 or $12 \%$ SDS-PAGE and transferred to a polyvinylidene difluoride membrane using a semidry transfer system (1 h, $12 \mathrm{~V})$. After blocking with $5 \%$ skim milk, the membrane was probed with a first antibody. Incubation was carried out overnight at $4^{\circ} \mathrm{C}$. The membrane was then washed three times and incubated with horseradish peroxidase-conjugated antirabbit IgG or anti-mouse IgG (Bio-Rad, Hercules, CA, USA) for $1 \mathrm{~h}$. Immunoreactive proteins on the membrane were visualized by treatment with a detection reagent (LumiGLO, Cell Signaling Technology). Optical densitometric scan was performed using NIH Image J software.

\section{Tube formation assay}

Tube formation assay was performed as previously described [42] with slight modification. Briefly, Matrigel was thawed at $4^{\circ} \mathrm{C}$ and $250 \mu$ l of the solution were added to each well in a 24-well plate and formed a gel at $37^{\circ} \mathrm{C}$ for $30 \mathrm{~min}$. HUVECs were suspended at $3 \times 10^{4}$ cells in $500 \mu \mathrm{l}$ of $3 \%$ FBS with or without $30 \mu \mathrm{M}$ DIF-
1, and then added to each well. After 8 h-incubation, the degree of tube formation was determined by counting the number of areas surrounded by tubes contained in 10 random fields, and expressed as mean \pm SE.

\section{Cell migration assay}

The effect of DIF-1 treatment on in vitro migration of HUVECs was determined using a Boyden Chamber [43]. The PET membrane $(8 \mu \mathrm{m}$ pore size, Greiner Bio-One, Frickenhausen, Germany) was pre-coated with $10 \mu \mathrm{g}$ of Matrigel. HUVECs were suspended at $5 \times 10^{4}$ cells in $100 \mu$ l of serum free DMEM with or without $30 \mu \mathrm{M}$ DIF-1 and seeded into the upper part of each chamber, whereas the lower compartments were filled with $600 \mu \mathrm{l}$ of DMEM supplemented with $0.1 \%$ bovine serum albumin and $20 \mathrm{ng} / \mathrm{ml}(0.52 \mathrm{nM})$ VEGF. After incubation for $10 \mathrm{~h}$ at $37^{\circ} \mathrm{C}$, non-migrated cells were scraped off with a cotton swab. Migrated cells on the lower surface of the membrane were fixed with $1 \%$ glutaraldehyde for $10 \mathrm{~min}$ and stained with $4 \%$ crystal violet for $30 \mathrm{~min}$. HUVEC migration was quantified by counting the number of cells in ten random fields per membrane. Data are expressed as mean \pm SE of cells/fields. 


\section{In vivo mouse Matrigel-plug assay}

In vivo angiogenesis was assayed as growth of blood vessels from mouse subcutaneous tissue into the exogenous Matrigel plug induced by VEGF or tumor cells [43]. For the analysis of VEGF-induced angiogenesis, Matrigel was prepared with $100 \mathrm{ng} / \mathrm{ml}$ (2.62 nM) VEGF, 20 units/ml heparin in the presence or absence of $30 \mu \mathrm{M}$ DIF- 1 at $4^{\circ} \mathrm{C}$. The liquid Matrigel was injected (final volume; $500 \mu \mathrm{l})$ into the flanks of C57BL/6 mice $(5 \sim 7$ weeks, $\mathrm{n}=7$ for each group) using a cold syringe and allowed to polymerize into a solid gel by body temperature. Seven days later, Matrigel plugs were extracted and samples were prepared for immunohistochemical analysis. To analysis for tumor-induced angiogenesis, $1 \times 10^{6}$ HeLa cells were mixed with liquid Matrigel in the presence or absence of $30 \mu \mathrm{M}$ DIF-1 (final volume; $500 \mu \mathrm{l}$ ). The mixture was injected subcutaneously in the flanks of 6 week-old nude mice (Kyudo, Saga, Japan). Two weeks later, the tumors were removed and samples were prepared for Western blot and immunohistochemical analyses. The handling and sacrificing of all animals were carried out in accordance with nationally prescribed guidelines, and ethical approval for studies was granted by the Animal Care and Use Committee of Kyushu University.

\section{Immunohistochemical analysis}

The removed Matrigel plugs and tumors were fixed in $10 \%$ buffered formalin followed by embedding in paraffin. Sections were then stained with hematoxylin-eosin staining and immunofluorescence staining. For immunofluorescence staining, primary PECAM-1/CD31 antibody (1:50 dilution) was applied to the sections and the slides were incubated overnight at $4^{\circ} \mathrm{C}$. The secondary antibody (Histofine, Nichirei, Tokyo, Japan) was applied to the sections and incubated for $1 \mathrm{~h}$. The slides were subsequently incubated with streptavidin-FITC (Invitrogen, Carlsbad, CA, USA) and the fluorescence strength was analyzed with Biozero fluorescence microscopy (Keyence, Osaka, Japan).

\section{Real-time quantitative reverse transcriptase-polymerase chain reaction}

Total RNAs were extracted from HUVECs using TRIzol (Invitrogen) and SV total RNA isolation system (Promega, Madison, WI, USA). First-strand cDNAs were synthesized from $2 \mu \mathrm{g}$ of total RNA using a high-capacity cDNA reverse transcription kit (Applied Biosystems, Carlsbad, CA, USA). The $100 \mathrm{ng}$ cDNA products were used for quantitative real-time PCR performed using TaqMan Universal PCR Master Mix (Applied Biosystems) and TaqMan MGB primers [VEGFR-2 (Hs00911700_m1) and GAPDH (Hs99999905_m1)] with an ABI Prism 7500 (Applied
Biosystems). The following PCR conditions were used: $50^{\circ}$ $\mathrm{C}$ for 2 minutes, then $95^{\circ} \mathrm{C}$ for 10 minutes, followed by 40 cycles at $95^{\circ} \mathrm{C}$ for 15 seconds and $60^{\circ} \mathrm{C}$ for 1 minute. Cycle threshold $\left(\mathrm{C}_{\mathrm{T}}\right)$ values for each gene were obtained for each sample. Differences in $\mathrm{C}_{\mathrm{T}}$ values between VEGFR-2 gene and endogenous control (GAPDH) were calculated and used for statistical analyses.

\section{Construction of reporter plasmid}

The 5'-flanking region of human VEGFR-2 [44] was amplified and cloned into PCR 2.1 (Invitrogen) for DNA sequencing. After confirming the sequence, DNA fragments $(-1003 /-48$ bp relative to the transcription start site) were excised with $S a c$ I and BglII and cloned into pGL3-Basic vectors (Promega).

\section{Luciferase reporter gene assay}

Cells were transiently transfected with plasmid DNA (TOPflash, FOPflash orVEGFR-2/pGL-3) and pRLSV40, a Renilla luciferase expression plasmid (Promega) to control transfection efficacy, using Superfect reagent (Qiagen, Hilden, Germany). To measure luciferase activities, Dual-luciferase Reporter Assay (Promega) and a luminometer (Lumat LB 9507; Berthold Technologies, Bad Wildbad, Germany) were used. Firefly luciferase activities were normalized to that of Renilla luciferase.

\section{Statistics}

The results are expressed as mean \pm SE. Statistical analysis of the differences between values were conducted using the Student's $t$-test or the one-way ANOVA with Bonferroni post-hoc tests (GraphPad Prism 5.0, GraphPad Software, La Jolla, CA, USA). A $P$ value $<0.05$ was considered statistically significant.

\section{Abbreviations}

HUVEC: human umbilical vein endothelial cell; BAEC: bovine aortic endothelial cell; VEGF: vascular endothelial growth factor; VEGFR: vascular endothelial growth factor receptor; DIF: differentiation-inducing factor; GSK$3 \beta$ : glycogen synthase kinase-3 $\beta$

\section{Acknowledgements}

This work was supported by a Grant-in-Aid for Scientific Research from the Ministry of Education, Culture, Sports, Science and Technology. We would like to express our gratitude for the technical support from Ms. Matsumoto (Department of Anatomic Pathology) and the Research Support Center, Graduate School of Medical Sciences, Kyushu University.

\section{Author details}

${ }^{1}$ Department of Clinical Pharmacology, Faculty of Medical Sciences, Kyushu University, Fukuoka 812-8582, Japan. ${ }^{2}$ Department of Anesthesia and Critical Care Medicine, Faculty of Medical Sciences, Kyushu University, Fukuoka 812 8582, Japan. ${ }^{3}$ Department of Applied Chemistry, Faculty of Engineering, Ehime University, Matsuyama 790-8577, Japan. ${ }^{4}$ Department of Molecular and Cellular Biochemistry, Faculty of Dental Sciences, Kyushu University, Fukuoka 812-8582, Japan. 


\section{Authors' contributions}

TY contributed to the major part of experimental work, analyzed and interpreted data, performed the statistics and drafted the manuscript. FT conceived the study, participated in its design and data analysis, and contributed with scientific discussion and manuscript preparation. FS contributed the production of reporter plasmid. YW provided DIF-1. SM, MH and SH interpreted data and contributed with scientific discussion. TS supervised the project and helped draft the manuscript. All authors read and approved the final manuscript.

\section{Competing interests}

The authors declare that they have no competing interests.

Received: 20 May 2010 Accepted: 16 September 2010

Published: 16 September 2010

\section{References}

1. Conway EM, Collen D, Carmeliet P: Molecular mechanisms of blood vessel growth. Cardiovasc Res 2001, 49:507-521.

2. Chavakis E, Dimmeler S: Regulation of endothelial cell survival and apoptosis during angiogenesis. Arterioscler Thromb Vasc Biol 2002, 22:887-893.

3. Gupta MK, Qin RY: Mechanism and its regulation of tumor-induced angiogenesis. World J Gastroenterol 2003, 9:1144-1155.

4. Wong ML, Prawira A, Kaye AH, Hovens CM: Tumour angiogenesis: its mechanism and therapeutic implications in malignant gliomas. J Clin Neurosci 2009, 16:1119-1130.

5. Ferrara N: Molecular and biological properties of vascular endothelial growth factor. J Mol Med 1999, 77:527-543.

6. Zachary I: VEGF signalling: integration and multi-tasking in endothelial cell biology. Biochem Soc Trans 2003, 31:1171-1177.

7. Olsson AK, Dimberg A, Kreuger J, Claesson-Welsh L: VEGF receptor signalling-in control of vascular function. Nat Rev Mol Cell Biol 2006, 7:359-371.

8. Hicklin DJ, Ellis LM: Role of the vascular endothelial growth factor pathway in tumor growth and angiogenesis. J Clin Oncol 2005, 23:1011-1027.

9. De Vries C, Escobedo JA, Ueno H, Houck K, Ferrara N, Williams LT: The fmslike tyrosine kinase, a receptor for vascular endothelial growth factor. Science 1992, 255:989-991.

10. Quinn TP, Peters KG, De Vries C, Ferrara N, Williams LT: Fetal liver kinase 1 is a receptor for vascular endothelial growth factor and is selectively expressed in vascular endothelium. Proc Natl Acad Sci USA 1993, 90:7533-7537.

11. Roskoski R Jr: VEGF receptor protein-tyrosine kinases: Structure and regulation. Biochem Biophys Res Commun 2008, 375:287-291.

12. Rahimi N, Dayanir V, Lashkari K: Receptor chimeras indicate that the vascular endothelial growth factor receptor-1 (VEGFR-1) modulates mitogenic activity of VEGFR-2 in endothelial cells. J Biol Chem 2000, 275:16986-16992.

13. Shibuya M: Differential roles of vascular endothelial growth factor receptor-1 and receptor-2 in angiogenesis. J Biochem Mol Biol 2006, 39:469-478.

14. Kowanetz M, Ferrara N: Vascular endothelial growth factor signaling pathways: therapeutic perspective. Clin Cancer Res 2006, 12:5018-5022.

15. Petrova TV, Makinen T, Alitalo K: Signaling via vascular endothelial growth factor receptors. Exp Cell Res 1999, 253:117-130.

16. Shibuya M, Claesson-Welsh L: Signal transduction by VEGF receptors in regulation of angiogenesis and lymphangiogenesis. Exp Cell Res 2006, 312:549-560

17. Morris HR, Taylor GW, Masento MS, Jermyn KA, Kay RR: Chemical structure of the morphogen differentiation inducing factor from Dictyostelium discoideum. Nature 1987, 328:811-814.

18. Kubohara Y: DIF-1, putative morphogen of D. discoideum, suppresses cell growth and promotes retinoic acid-induced cell differentiation in HL-60. Biochem Biophys Res Commun 1997, 236:418-422.

19. Miwa Y, Sasaguri T, Kosaka C, Taba Y, Ishida A, Abumiya T, Kubohara Y: Differentiation-inducing factor-1, a morphogen of dictyostelium, induces $\mathrm{G}_{1}$ arrest and differentiation of vascular smooth muscle cells. Circ Res 2000, 86:68-75.
20. Takahashi-Yanaga F, Taba Y, Miwa Y, Kubohara Y, Watanabe Y, Hirata M, Morimoto S, Sasaguri T: Dictyostelium differentiation-inducing factor-3 activates glycogen synthase kinase-3 $3 \beta$ and degrades cyclin D1 in mammalian cells. J Biol Chem 2003, 278:9663-9670.

21. Mori J, Takahashi-Yanaga F, Miwa Y, Watanabe Y, Hirata M, Morimoto S, Shirasuna K, Sasaguri T: Differentiation-inducing factor-1 induces cyclin D1 degradation through the phosphorylation of Thr286 in squamous cell carcinoma. Exp Cell Res 2005, 310:426-433.

22. Yasmin T, Takahashi-Yanaga F, Mori J, Miwa Y, Hirata M, Watanabe $Y$, Morimoto $S$, Sasaguri T: Differentiation-inducing factor-1 suppresses gene expression of cyclin D1 in tumor cells. Biochem Biophys Res Commum 2005, 338:903-909

23. Matsuzaki E, Takahashi-Yanaga F, Miwa Y, Hirata M, Watanabe Y, Sato N, Morimoto S, Hirofuji T, Maeda K, Sasaguri T: Differentiation-inducing factor-1 alters canonical Wnt signaling and suppressed alkaline phosphatase expression in osteoblast-like cell lines. J Bone Miner Res 2006, 21:1307-1316.

24. Goodwin AM, D'Amore PA: Wnt signaling in the vasculature. Angiogenesis 2002, 5:1-9.

25. Masckauchan TN, Shawber CJ, Funahashi Y, Li CM, Kitajewski J: Wnt/betacatenin signaling induces proliferation, survival and interleukin-8 in human endothelial cells. Angiogenesis 2005, 8:43-51.

26. Parmalee NL, Kitajewski J: Wnt signaling in angiogenesis. Curr Drug Targets 2008, 9:558-564.

27. Zerlin M, Julius MA, Kitajewski J: Wnt/Frizzled signaling in angiogenesis. Angiogenesis 2008, 11:63-69.

28. Wang $\mathrm{Y}$, Nakayama N: Wnt and BMP signaling are both required for hematopoietic cell development from human ES cells. Stem Cell Res 2009, 3:113-125.

29. Takahashi T, Yamaguchi S, Chida K, Shibuya M: A single autophosphorylation site on KDR/Flk-1 is essential for VEGF-Adependent activation of PLC $-\gamma$ and DNA synthesis in vascular endothelial cells. EMBO J 2001, 20:2768-2778.

30. Rahimi N: VEGFR-1 and VEGFR-2: two non-identical twins with a unique physiognomy. Front Biosci 2006, 11:818-829.

31. Blanes MG, Oubaha M, Rautureau Y, Gratton JP: Phosphorylation of tyrosine 801 of vascular endothelial growth factor receptor- 2 is necessary for Akt-dependent endothelial nitric-oxide synthase activation and nitric oxide release from endothelial cells. J Biol Chem 2007, 282:10660-10669.

32. Miyagi M, Miwa Y, Takahashi-Yanaga F, Morimoto S, Sasaguri T: Activator protein-1 mediates shear stress-induced prostaglandin D synthase gene expression in vascular endothelial cells. Arterioscler Thromb Vasc Biol 2005, 25:970-975.

33. Zhang X, Gaspard JP, Chung DC: Regulation of vascular endothelial growth factor by the Wnt and K-ras pathways in colonic neoplasia. Cancer Res 2001, 61:6050-6054.

34. Easwaran V, Lee SH, Inge L, Guo L, Goldbeck C, Garrett E, Wiesmann M, Garcia PD, Fuller JH, Chan V, Randazzo F, Gundel R, Warren RS, Escobedo J, Aukerman SL, Taylor RN, Fantl WJ: $\beta$-Catenin regulates vascular endothelial growth factor expression in colon cancer. Cancer Res 2003, 63:3145-3153.

35. Meissner M, Reichenbach G, Stein M, Hrgovic I, Kaufmann R, Gille J: Downregulation of vascular endothelial growth factor receptor 2 is a major molecular determinant of proteasome inhibitor-mediated antiangiogenic action in endothelial cells. Cancer Res 2009, 69:1976-1984.

36. Cheng CW, Smith SK, Charnock-Jones DS: Wnt-1 signaling inhibits human umbilical vein endothelial cell proliferation and alters cell morphology. Exp Cell Res 2003, 291:415-425.

37. Nimmagadda S, Geetha-Loganathan P, Scaal M, Christ B, Huang R: FGFs, Wnts and BMPs mediate induction of VEGFR-2 (Quek-1) expression during avian somite development. Dev Biol 2007, 305:421-429.

38. Samarzija I, Sini P, Schlange T, MacDonald G, Hynes NE: Wnt3a regulates proliferation and migration of HUVEC via canonical and non-canonical Wnt signaling pathways. Biochem Biophys Res Commun 2009, 386:449-454.

39. Weinberg RA: The retinoblastoma protein and cell cycle control. Cell 1995, 81:323-330.

40. Yasui M, Yamamoto $H$, Ngan CY, Damdinsuren B, Sugita $Y$, Fukunaga $H$, Gu J, Maeda M, Takemasa I, Ikeda M, Fujio Y, Sekimoto M, Matsuura N, Weinstein IB, Monden M: Antisense to cyclin D1 inhibits vascular endothelial growth factor-stimulated growth of vascular endothelial 
cells: implication of tumor vascularization. Clin Cancer Res 2006, 12:4720-4729.

41. Masento MS, Morris HR, Taylor GW, Johnson SJ, Skapski AC, Kay RR: Differentiation-inducing factor from the slime mould Dictyostelium discoideum and its analogues. Synthesis, structure and biological activity. Biochem J 1988, 256:23-28.

42. Kawasaki J, Hirano K, Hirano M, Nishimura J, Nakatsuka A, Fujishima M, Kanaide $\mathrm{H}$ : Dissociation between the $\mathrm{Ca}(2+)$ signal and tube formation induced by vascular endothelial growth factor in bovine aortic endothelial cells. Eur J Pharmacol 2000, 398:19-29.

43. Margheri F, Serrati S, Lapucci A, Anastasia C, Giusti B, Pucci M, Torre E, Bianchini F, Calorini L, Albini A, Ventura A, Fibbi G, Del Rosso M: Systemic sclerosis-endothelial cell antiangiogenic pentraxin 3 and matrix metalloprotease 12 control human breast cancer tumor vascularization and development in mice. Neoplasia 2009, 11:1106-1115.

44. Patterson C, Perrella MA, Hsieh CM, Yoshizumi M, Lee ME, Haber E: Cloning and functional analysis of the promoter for $\mathrm{KDR} / \mathrm{flk}-1$, a receptor for vascular endothelial growth factor. J Biol Chem 1995, 270:23111-23118.

doi:10.1186/1476-4598-9-245

Cite this article as: Yoshihara et al:: Anti-angiogenic effects of differentiation-inducing factor-1 involving VEGFR-2 expression inhibition independent of the Wnt/ $\beta$-catenin signaling pathway. Molecular Cancer 2010 9:245

\section{Submit your next manuscript to BioMed Central} and take full advantage of:

- Convenient online submission

- Thorough peer review

- No space constraints or color figure charges

- Immediate publication on acceptance

- Inclusion in PubMed, CAS, Scopus and Google Scholar

- Research which is freely available for redistribution

Submit your manuscript at www.biomedcentral.com/submit 